\title{
Synthesis, Characterization and Thermal Behaviour of Solid 2-Methoxycinnamylidenepyruvate of Light Trivalent Lanthanides
}

\author{
C. T. Carvalho, ${ }^{a}$ A. B. Siqueira, ${ }^{a}$ O. Treu-Filho, ${ }^{b}$ E. Y. Ionashiro ${ }^{b}$ and M. Ionashiro ${ }^{* a}$ \\ ${ }^{a}$ Instituto de Química, Universidade Estadual Paulista, CP 355, 14801-970 Araraquara-SP, Brazil \\ ${ }^{b}$ Instituto de Química, Universidade Federal de Goiás, Campus II, 74001-979 Goiânia-GO, Brazil
}

\begin{abstract}
Compostos Ln-2-MeO-CP no estado sólido, em que o símbolo Ln representa lantanídeos trivalentes ( $\mathrm{La}, \mathrm{Ce}, \mathrm{Pr}, \mathrm{Nd}, \mathrm{Sm}, \mathrm{Eu}, \mathrm{Gd}$ ) e 2-MeO-CP é 2-metoxicinamalpiruvato, foram sintetizados neste trabalho. As técnicas de termogravimetria e análise térmica diferencial simultâneas (TGDTA), calorimetria exploratória diferencial (DSC), difratometria de raios X, espectroscopia de absorção no infravermelho (espectros experimental e teórico) e complexometria foram usadas para caracterizar e estudar o comportamento térmico destes compostos. Os resultados informam sobre a composição e a estabilidade dos complexos isolados.
\end{abstract}

Solid state Ln-2-MeO-CP compounds, where Ln stands for light trivalent lanthanides (La, Ce, $\mathrm{Pr}, \mathrm{Nd}, \mathrm{Sm}, \mathrm{Eu}, \mathrm{Gd}$ ) and 2-MeO-CP is 2-methoxycinnamylidenepyruvate, were synthesized in this work. Simultaneous thermogravimetry and differential thermal analysis (TG-DTA), differential scanning calorimetry (DSC), X-ray powder diffractometry, experimental and theoretical infrared spectroscopy and complexometry were used to characterize and to study the thermal behaviour of these compounds. The results led to information regarding the composition and stability of the isolated complexes.

Keywords: light lanthanides, 2-methoxycinnamylidenepyruvate, characterization, thermal behaviour, DFT

\section{Introduction}

Syntheses of cinnamylidenepyruvic acid (HCP), as well as of its phenyl-substituted derivatives, have been reported. ${ }^{1}$ These acids are of continuing interest as intermediates in pharmacological, industrial and chemical syntheses, in development of enzyme inhibitors and drugs, as model substrates of enzymes, and in other studies. ${ }^{2}$

Several metal ion complexes of phenyl-substituted derivatives of cinnamylidenepyruvate, $\mathrm{C}_{6} \mathrm{H}_{5}(\mathrm{CH})_{4} \mathrm{C}(\mathrm{O}) \mathrm{COO}^{-}$ $(\mathrm{CP})$, have been investigated in aqueous solutions ${ }^{3}$ and in the solid state..$^{4-9}$ These works reported the thermodynamic stability $\left(\beta_{1}\right)$ and spectroscopic parameters $\left(\varepsilon_{1 \max }, \lambda_{1 \max }\right)$ in aqueous solutions associated with 1:1 complex species. They also report the synthesis and investigation of the compounds in the solid state by means of thermogravimetry (TG), differential thermal analysis (DTA), differential scanning calorimetry (DSC), X-ray powder diffractometry and other methods of analysis. Establishment of the stoichiometry

\footnotetext{
*e-mail: massaoi@iq.unesp.br
}

and the details of the thermal decomposition were the main purpose of these studies. However, the synthesis and characterization of compounds derived from 2-MeO-HCP have not been reported.

As an extension of the work reported in references 6-9, the objective of the present research was to prepare 2-methoxycinnamylidenepyruvic acid and 2-methoxycinnamylidenepyruvate complexes of light trivalent lanthanides in the solid state. The compounds were investigated by means of complexometry, X-ray powder diffractometry, infrared spectroscopy, simultaneous thermogravimetry and differential thermal analysis (TGDTA) and differential scanning calorimetry (DSC). The results allowed us to acquire information concerning these compounds in the solid state, including their thermal stability and thermal decomposition.

\section{Experimental}

The 2-methoxycinnamaldehyde, $\left(\mathrm{CH}_{3} \mathrm{O}\right) \mathrm{C}_{6} \mathrm{H}_{4}(\mathrm{CH})_{2} \mathrm{CHO}$, $96 \%$ pure and predominantly trans, was obtained from 
Aldrich. Sodium pyruvate, $\mathrm{CH}_{3} \mathrm{C}(\mathrm{O}) \mathrm{COONa}$, $99 \%$ pure, was obtained from Sigma.

Sodium 2-methoxycinnamylidenepyruvate (Na-2-MeO$\mathrm{CP}$ ) and its corresponding acid were both synthesized following a procedure described in the literature, ${ }^{9}$ with the following modifications: an aqueous solution of sodium pyruvate $(8.71 \mathrm{~g}$ per $10 \mathrm{~mL}$ ) was added under continuous stirring to $20 \mathrm{~mL}$ of a methanolic solution of 2-methoxycinnamaldehyde (13.23 g). Sixty three milliliters of an aqueous sodium hydroxide solution $5 \%(\mathrm{w} / \mathrm{v})$ were slowly added, while the reacting system was stirred and cooled in an ice bath. The addition rate of the alkali was regulated so that the temperature remained between 278 and $282 \mathrm{~K}$. The formation of a pale yellow precipitate was observed during the addition of the sodium hydroxide solution.

The system was left to stand for about $3 \mathrm{~h}$ at room temperature (296-301 K). The pale yellow precipitate (impure sodium 2-methoxycinnamylidenepyruvate) was filtered and washed with $100 \mathrm{~mL}$ portions of methanol to remove most of the unreacted aldehyde and secondary products. The crude product was dissolved in water $(200 \mathrm{~mL})$ and concentrated hydrochloric acid $\left(12 \mathrm{~mol} \mathrm{~L}^{-1}\right)$ was added to the solutions, under continuous stirring, until total precipitation of the 2-methoxycinnamylidenepyruvic acid (4.8 g).

Aqueous solutions of Na-2-MeO-CP, $0.1 \mathrm{~mol} \mathrm{~L}^{-1}$, were prepared by direct weighing of the salt. Lanthanide chlorides were prepared from the corresponding metal oxides, except for cerium, by treatment with concentrated hydrochloric acid. The resulting solutions were evaporated to near dryness and the residues were redissolved in distilled water. The solutions were again evaporated to near dryness to eliminate the excess of hydrochloric acid. The residues were redissolved in distilled water, transferred to a volumetric flask and then diluted in order to give ca. $0.1 \mathrm{~mol} \mathrm{~L}^{-1}$ solutions, whose $\mathrm{pH}$ was adjusted to around 5 by adding diluted sodium hydroxide or hydrochloric acid solutions. Cerium(III) was obtained from its nitrate and a ca. $0.1 \mathrm{~mol} \mathrm{~L}^{-1}$ aqueous solution of this ion was prepared by direct weighing of the salt.

The solid state compounds were prepared by slowly adding the solution of the proligand to the respective metal chloride or nitrate solution, under continuous stirring, until total precipitation of the metal ions. The precipitates were washed with distilled water until the nitrate and chloride ions were totally eliminated. The mixtures were then filtered through and dried on Whatman number 42 filter paper and kept in a desiccator over anhydrous calcium chloride.

For the compounds in the solid state, TG curves were used to determine the hydration water, ligand and metal contents. The metal ions were also determined by complexometric tritration with standard EDTA solution, ${ }^{10,11}$ after igniting the compounds to their respective oxides and then dissolving them in hydrochloric acid solution.

$\mathrm{X}$-ray powder patterns were obtained using a Siemens D-5000 X-ray diffractometer, employing $\mathrm{CuK}_{\alpha}$ radiation $(\lambda=1.541 \AA)$ and a setting of $40 \mathrm{kV}$ and $20 \mathrm{~mA}$.

Infrared spectra for $\mathrm{Na}-2-\mathrm{MeO}-\mathrm{CP}$, as well as for its metal ion compounds, were run on a Nicolet Model Impact 400 FTIR instrument within the $4000-400 \mathrm{~cm}^{-1}$ range. The solid samples were pressed into $\mathrm{KBr}$ pellets.

Simultaneous TG-DTA and DSC curves were obtained with two thermal analysis systems, model SDT 2960 and DSCQ10, both from TA Instruments. The purge gas was an air flow of $100 \mathrm{~mL} \mathrm{~min}^{-1}$ for the TG-DTA and $50 \mathrm{~mL} \mathrm{~min}^{-1}$ for the DSC. Heating rates of 20 degree $\mathrm{min}^{-1}$ for the TGDTA and 40 degree min $^{-1}$ for the DSC were adopted, with samples weighing about $7 \mathrm{mg}$ for the TG-DTA and $5 \mathrm{mg}$ for the DSC. Alumina and aluminium crucibles, the latter with perforated covers, were used for the TG-DTA and the DSC, respectively.

\section{Theoretical calculations}

In the present investigations, the quantum chemical approach employed was the Becke three-parameter hybrid method $^{12}$ using the Lee-Yang-Par (LYP) correlation functional. ${ }^{13}$ The basis sets used for calculations were the SDD Stuttgart (D95V up to $\mathrm{Ar}^{14}$ and Stuttgart, Dresden ECPs on the remainder of the periodic table). ${ }^{15}$ The molecular calculations optimized in the work were carried out using the Gaussian 03 routine. ${ }^{16}$ The crystal geometry of the $\mathrm{La}(2-\mathrm{MeO}-\mathrm{CP})_{3}$ is not available in the literature, so a geometry was optimized using Berny Algorithm, ${ }^{17}$ see Figure 1. It was also shown that compound 1, Figure 1a, is $41.8 \mathrm{~kJ} \mathrm{~mol}^{-1}$ more stable than the analogous one, Figure $1 b$. The structure parameters obtained for the most stable compound are shown in Table 1.

The theoretical infrared spectrum was calculated using a harmonic field ${ }^{18}$ based on $C_{l}$ symmetry (electronic state ${ }^{1} \mathrm{~A}$ ).

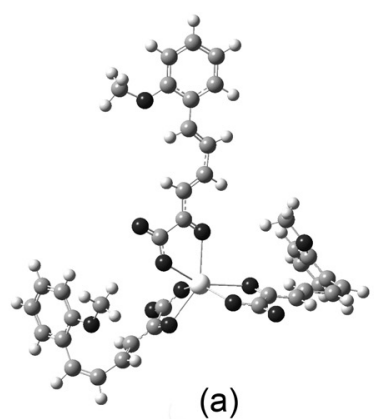

(a)

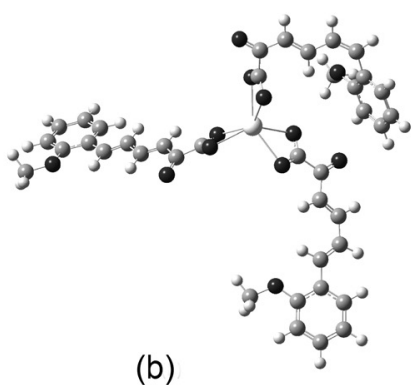

(b)
Figure 1. Theoretical 3D structure of (a) $\mathrm{La}(\mathrm{L})_{3}$ - lanthanum coordination by $\alpha$-ketonic carbonyl and carboxylate group; (b) $\mathrm{La}(\mathrm{L})_{3}$ - lanthanum coordination by carboxylate group. 
Table 1. Theoretical geometry parameters of lanthanum(III) complexes with 2-methoxycinnamylidenepyruvate

\begin{tabular}{lc}
\hline $\mathrm{d} \mathrm{O}_{\text {coo }}-\mathrm{La}$ & $2.37 \AA$ \\
$\mathrm{d} \mathrm{O}_{\mathrm{co}}-\mathrm{La}$ & $2.56 \AA$ \\
$\mathrm{d} \mathrm{C}_{\mathrm{co}}-\mathrm{O}$ & $1.25 \AA$ \\
$\mathrm{d} \mathrm{C}_{\mathrm{coo}}-\mathrm{OLa}$ & $1.29 \AA$ \\
$\mathrm{d} \mathrm{H}_{3} \mathrm{CO}-\mathrm{C}$ & $1.37 \AA$ \\
$\mathrm{d} \mathrm{LaOC}-\mathrm{O}$ & $1.22 \AA$ \\
$<\mathrm{O}-\mathrm{La}-\mathrm{O}$ & $62.15^{\circ}$ \\
$<\mathrm{La}-\mathrm{O}_{\mathrm{co}}-\mathrm{C}$ & $121.55^{\circ}$ \\
$<\mathrm{La}-\mathrm{O}$ coo $-\mathrm{C}$ & $129.37^{\circ}$ \\
$<\mathrm{O}_{\mathrm{co}}-\mathrm{C}-\mathrm{C}_{\mathrm{coo}}$ & $115.25^{\circ}$ \\
$<\mathrm{O}_{\text {coo }}-\mathrm{C}-\mathrm{C}$ & $111.59^{\circ}$ \\
\hline
\end{tabular}

d: distance, < means angle; co: $\alpha$-ketonic carbonyl; coo: carboxylate group.

Frequency values (not scaled), relative intensities, assignments and description of vibrational modes are presented. The calculation of vibrational frequencies was also employed to determine whether the optimized geometry constitutes minimum or saddle points. The principal infrared active fundamental modes assignments and descriptions were done by the Gauss View 3.0 graphics. ${ }^{19}$

\section{Results and Discussion}

The analytical and thermoanalytical (TG) data are shown in Table 2. These results permitted us to establish the stoichiometry of these compounds, which are in agreement with the general formula $\mathrm{Ln}(2-\mathrm{MeO}-\mathrm{CP})_{3} \cdot \mathrm{H}_{2} \mathrm{O}$, where $\mathrm{Ln}$ represents light trivalent lanthanides and $2-\mathrm{MeO}-\mathrm{CP}$ is 2-methoxycinnamylidenepyruvate.

The X-ray powder patterns showed that all the compounds were obtained in the amorphous state. The amorphous state is undoubtedly related to the low solubility of these compounds, as has already been observed for lanthanides with other phenyl-substituted derivatives of CP. ${ }^{6}$

Infrared spectroscopic data on 2-methoxycinnamylidenepyruvate and its compounds of light trivalent lanthanides are shown in Table 3. The investigation was focused mainly within the $1700-1400 \mathrm{~cm}^{-1}$ range, because this region is potentially the most informative in order to assign coordination sites. For sodium 2-methoxycinnamylidenepyruvate, the bands centered at $1581 \mathrm{~cm}^{-1}$ and $1668 \mathrm{~cm}^{-1}$ were assigned to ketonic carbonyl stretching and antisymmetric carboxylate vibration respectively. The sodium cation interacts with both the $\alpha-\mathrm{C}=\mathrm{O}$ and $\mathrm{COO}^{-}$groups. ${ }^{20}$ For the $\mathrm{Ln}$ compounds the assignments are essentially identical, with bands centered at $1560 \mathrm{~cm}^{-1}$ (ketonic carbonyl stretching) and 1629-1647 $\mathrm{cm}^{-1}$ (antisymmetric carboxylate vibration), suggesting lanthanide coordination both by the $\alpha$-ketonic carbonyl and carboxylate groups of the ligand. This assignments were indicated by theoretical calculations, as seen in Figure 2.

A comparative analysis of the experimental and theoretical spectra permitted to verify that: $(i)$ the first assignment shows a strong contribution at $1560 \mathrm{~cm}^{-1}$, suggesting ketonic carbonyl stretching, while the theoretical results show the corresponding peak at $1510 \mathrm{~cm}^{-1}$ with discrepancies of $3.21 \%$; (ii) the second assignment shows a strong contribution at $1629 \mathrm{~cm}^{-1}$ suggesting a $v_{\text {asym }}\left(\mathrm{COO}^{-}\right)$assignment, while the theoretical results show the corresponding peak at $1613 \mathrm{~cm}^{-1}$ with discrepancies of $0.98 \%$. The theoretical results are therefore in agreement with the experimental data.

Simultaneous TG-DTA curves of the compounds are shown in Figure 3. These curves exhibit mass losses in three (Ce) or five ( $\mathrm{La}, \mathrm{Pr}, \mathrm{Nd}, \mathrm{Sm}, \mathrm{Eu}, \mathrm{Gd})$ consecutive and/or overlapping steps and thermal events corresponding to these losses. A close similarity is noted concerning the TG-DTA profiles of praseodymium and europium, or between neodymium, samarium and gadolinium compounds, while the lanthanum and cerium complexes show TG-DTA profiles characteristic of each compound.

Table 2. Analytical and thermoanalytical (TG) data of the compounds. Ln: trivalent lanthanides; 2-MeO-CP = 2-methoxycinnamylidenepyruvate

\begin{tabular}{|c|c|c|c|c|c|c|c|c|}
\hline \multirow{2}{*}{ Compound } & \multicolumn{3}{|c|}{$\operatorname{Ln} /(\%)$} & \multicolumn{2}{|c|}{ Ligand lost / (\%) } & \multicolumn{2}{|c|}{ Water / (\%) } & \multirow{2}{*}{ Residue } \\
\hline & Calc. & TG & EDTA & Calc. & TG & Calc. & TG & \\
\hline $\mathrm{La}(2-\mathrm{MeO}-\mathrm{CP})_{3} \cdot \mathrm{H}_{2} \mathrm{O}$ & 16.33 & 16.27 & 16.12 & 78.73 & 78.92 & 2.12 & 2.18 & $\mathrm{La}_{2} \mathrm{O}_{3}$ \\
\hline $\mathrm{Ce}(2-\mathrm{MeO}-\mathrm{CP})_{3} \cdot \mathrm{H}_{2} \mathrm{O}$ & 16.45 & 16.19 & 16.47 & 77.68 & 77.63 & 2.12 & 2.14 & $\mathrm{CeO}_{2}$ \\
\hline $\operatorname{Pr}(2-\mathrm{MeO}-\mathrm{CP})_{3} \cdot \mathrm{H}_{2} \mathrm{O}$ & 16.53 & 16.58 & 16.60 & 77.92 & 77.94 & 2.11 & 2.01 & $\mathrm{Pr}_{6} \mathrm{O}_{11}$ \\
\hline $\mathrm{Nd}(2-\mathrm{MeO}-\mathrm{CP})_{3} \cdot \mathrm{H}_{2} \mathrm{O}$ & 16.85 & 16.38 & 16.56 & 78.24 & 78.49 & 2.11 & 2.20 & $\mathrm{Nd}_{2} \mathrm{O}_{3}$ \\
\hline $\mathrm{Sm}(2-\mathrm{MeO}-\mathrm{CP})_{3} \cdot \mathrm{H}_{2} \mathrm{O}$ & 17.44 & 16.59 & 16.90 & 77.69 & 78.15 & 2.09 & 2.25 & $\mathrm{Sm}_{2} \mathrm{O}_{3}$ \\
\hline $\mathrm{Eu}(2-\mathrm{MeO}-\mathrm{CP})_{3} \cdot \mathrm{H}_{2} \mathrm{O}$ & 17.54 & 17.69 & 17.75 & 77.61 & 77.66 & 2.08 & 2.06 & $\mathrm{Eu}_{2} \mathrm{O}_{3}$ \\
\hline $\mathrm{Gd}(2-\mathrm{MeO}-\mathrm{CP})_{3} \cdot \mathrm{H}_{2} \mathrm{O}$ & 18.04 & 17.91 & 18.17 & 77.14 & 77.19 & 2.07 & 1.93 & $\mathrm{Gd}_{2} \mathrm{O}_{3}$ \\
\hline
\end{tabular}




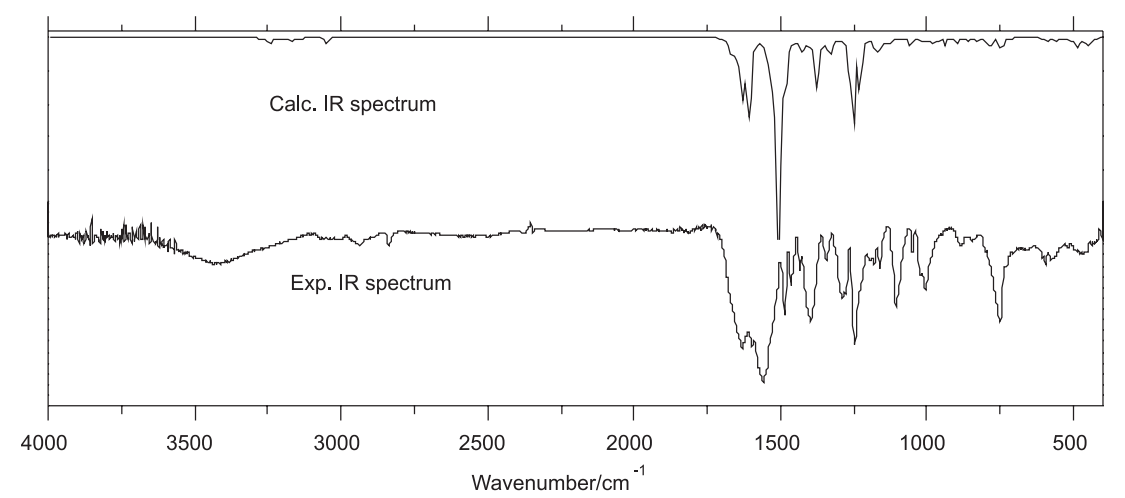

Figure 2. The experimental and calculated infrared spectra of $\mathrm{La}(\mathrm{L})_{3}$.

Table 3. Spectroscopic data for sodium 2-methoxycinnamylidenepyruvate and for its compounds with light trivalent lanthanides; FTIR spectra / $\mathrm{cm}^{-1}$

\begin{tabular}{|c|c|c|c|c|}
\hline Compound & $v_{(\mathrm{O}-\mathrm{H})} \mathrm{H}_{2} \mathrm{O}^{\mathrm{a}}$ & $v_{C=0}^{b}$ & $\left.v_{\text {asym(COO- }}\right)^{\mathrm{c}}$ & $\Delta v_{\mathrm{sym}\left(\mathrm{COO}^{-}\right)^{\mathrm{c}}}$ \\
\hline $\mathrm{Na}(2-\mathrm{MeO}-\mathrm{CP})_{3} \cdot \mathrm{H}_{2} \mathrm{O}$ & - & $1581_{\mathrm{s}}$ & $1668_{\mathrm{s}}$ & $1402_{\mathrm{s}}$ \\
\hline $\mathrm{La}(2-\mathrm{MeO}-\mathrm{Bz})_{3} \cdot \mathrm{H}_{2} \mathrm{O}$ & $3436_{\mathrm{br}}$ & $1560 \mathrm{~s}$ & $1629_{\mathrm{s}}$ & $1398_{\mathrm{s}}$ \\
\hline $\mathrm{Ce}(2-\mathrm{MeO}-\mathrm{Bz})_{3} \cdot \mathrm{H}_{2} \mathrm{O}$ & $3417_{\text {br }}$ & $1560_{\mathrm{s}}$ & $1629 \mathrm{~s}$ & $1406_{s}$ \\
\hline $\operatorname{Pr}(2-\mathrm{MeO}-\mathrm{Bz})_{3} \cdot \mathrm{H}_{2} \mathrm{O}$ & $3402_{\mathrm{br}}$ & $1560_{\mathrm{s}}$ & $1637_{\mathrm{s}}$ & $1406_{s}$ \\
\hline $\mathrm{Nd}(2-\mathrm{MeO}-\mathrm{Bz})_{3} \cdot \mathrm{H}_{2} \mathrm{O}$ & $3404_{\mathrm{br}}$ & $1560_{\mathrm{s}}$ & $1637_{\mathrm{s}}$ & $1411_{\mathrm{s}}$ \\
\hline $\mathrm{Sm}(2-\mathrm{MeO}-\mathrm{Bz})_{3} \cdot \mathrm{H}_{2} \mathrm{O}$ & $3431_{\mathrm{br}}$ & $1560_{\mathrm{s}}$ & $1641_{\mathrm{s}}$ & $1415_{\mathrm{s}}$ \\
\hline $\mathrm{Eu}(2-\mathrm{MeO}-\mathrm{CP})_{3} \cdot \mathrm{H}_{2} \mathrm{O}$ & $3419_{\mathrm{br}}$ & $1560_{\mathrm{s}}$ & $1637_{\mathrm{s}}$ & $1407_{\mathrm{s}}$ \\
\hline $\mathrm{Gd}(2-\mathrm{MeO}-\mathrm{CP})_{3} \cdot \mathrm{H}_{2} \mathrm{O}$ & $3431_{\mathrm{br}}$ & $1560_{\mathrm{s}}$ & $1641_{\mathrm{s}}$ & $1409_{\mathrm{s}}$ \\
\hline
\end{tabular}

2-MeO-CP = 2-methoxycinnamylidenepyruvate; br: broad; s: strong; ${ }^{\mathrm{a}} \mathrm{v}_{(\mathrm{O}-\mathrm{H})}$ : hydroxyl group stretching frequency; ${ }^{\mathrm{b}} \mathrm{v}_{\mathrm{C}=0}$ : ketonic carbonyl stretching frequency; ${ }^{c} v_{\text {asym ((COO) }}$ and $v_{\text {sym ((COO})}$ : antisymmetric and symmetric vibrations of the $\mathrm{COO}^{-}$group.

These curves also show that the first mass loss for all the compounds occurs in the same temperature range (333-393 K), showing that the thermal behaviour up to this temperature is not dependent on the nature of the metal ion. However, the features shown by the next steps of the thermal decomposition, as well as the mass lost in each step, are characteristic of each compound, and depend on the metal ion present.

For all the compounds, the first mass loss, which is associated to the endothermic peak at $368-373 \mathrm{~K}$, is ascribed to the dehydration that occurs in a single step and is a slow process. This behaviour seems to be characteristic of compounds obtained in the amorphous state.

After dehydration, the mass losses observed above $403 \mathrm{~K}$ are due to the thermal decomposition of the anhydrous compounds. For the anhydrous lanthanum compound, Figure 3a, the thermal decomposition occurs in four steps. The first two up to $813 \mathrm{~K}$, corresponding to exothermic events, are attributed to the oxidation of the organic matter, thus forming a mixture of carbonaceous residue and lanthanum dioxicarbonate $\left(\mathrm{La}_{2} \mathrm{O}_{2} \mathrm{CO}_{3}\right)$. The third mass loss, that occurs in a slow process (813-943 K), corresponding to a small plus a large exothermic event, is ascribed to the oxidation of the carbonaceous residue. The last mass loss (943-993 K), corresponding to the endothermic peak at $985 \mathrm{~K}$, is in agreement with the thermal decomposition of the intermediate $\mathrm{La}_{2} \mathrm{O}_{2} \mathrm{CO}_{3}$ (calculated $=$ $2.58 \%$; $\mathrm{TG}=2.5 \%$ ), leading to lanthanum oxide, $\mathrm{La}_{2} \mathrm{O}_{3}$.

For the anhydrous cerium compound, Figure $3 \mathrm{~b}$, the thermal decomposition occurs in two overlapping steps up to $723 \mathrm{~K}$, corresponding to exothermic events with the formation of cerium(IV) oxide, $\mathrm{CeO}_{2}$, as the final residue. No intermediate is formed, probably due to the smaller temperature range of the thermal decomposition provoked by the oxidation reaction of cerium(III) to cerium(IV), together with the oxidation of the organic matter, both being exothermic reactions. This behaviour had already been observed for other cerium compounds. ${ }^{6,7}$

For the other anhydrous compounds, Figure 3(c-g), the mass losses up to $783 \mathrm{~K}(\mathrm{Pr}), 853 \mathrm{~K}(\mathrm{Nd}) 823 \mathrm{~K}(\mathrm{Sm}$, $\mathrm{Eu})$ and $903 \mathrm{~K}(\mathrm{Gd})$, corresponding to exothermic events, are attributed to the oxidation of the organic matter with the formation of a mixture of dioxycarbonate and oxide in no simple stoichiometric relationship. Tests with hydrochloric acid solution on samples heated up to the temperature of formation of this intermediate, as indicated 

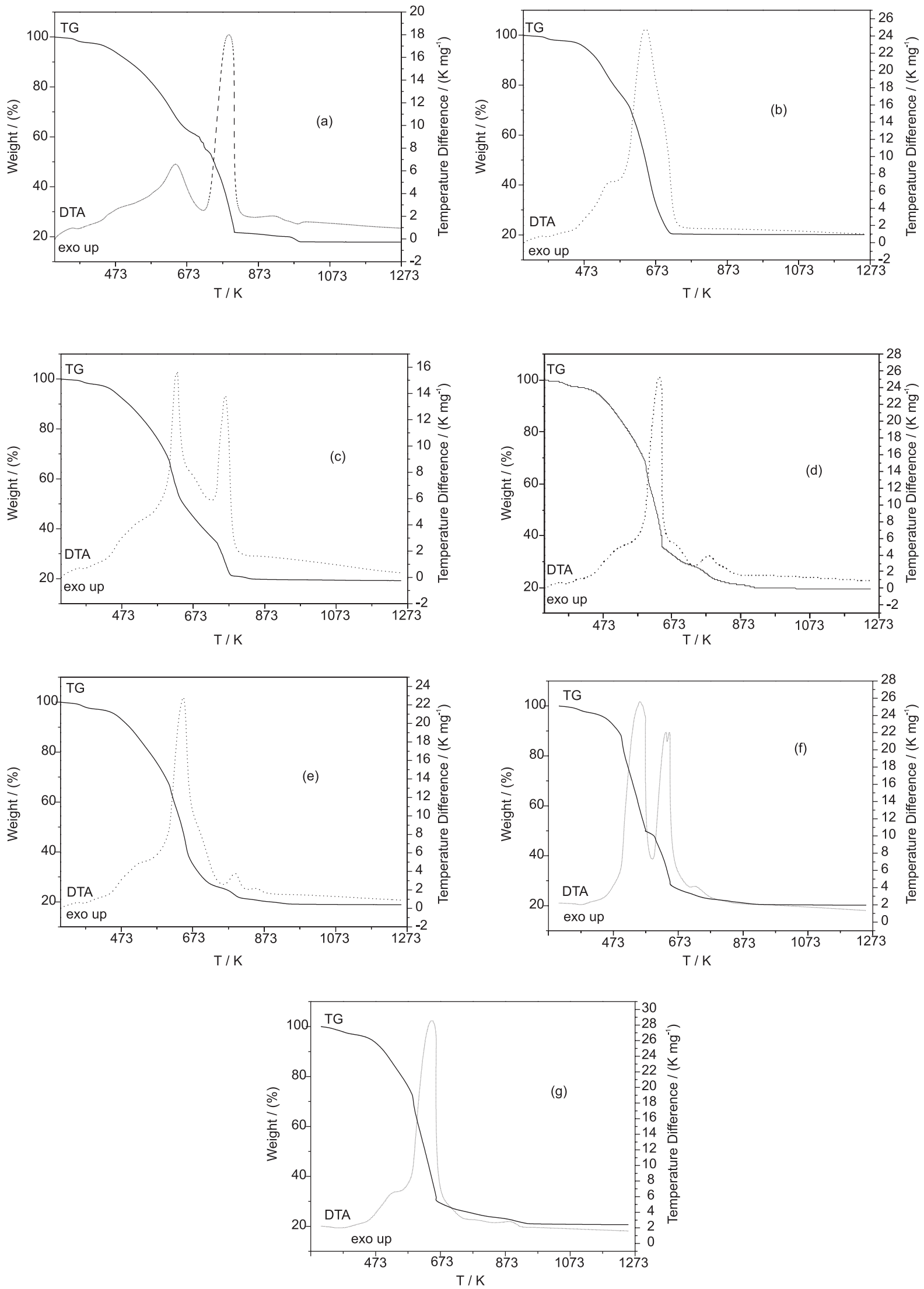

Figure 3. TG-DTA curves of the compounds: (a) $\mathrm{La}(\mathrm{L})_{3} \cdot \mathrm{H}_{2} \mathrm{O}(\mathrm{m}=7.2067 \mathrm{mg})$, (b) $\mathrm{Ce}(\mathrm{L})_{3} \cdot \mathrm{H}_{2} \mathrm{O}(\mathrm{m}=7.3748 \mathrm{mg}),(\mathrm{c}) \mathrm{Pr}(\mathrm{L}){ }_{3} \cdot \mathrm{H}_{2} \mathrm{O}(\mathrm{m}=7.0587 \mathrm{mg})$, (d) $\mathrm{Nd}(\mathrm{L}){ }_{3} \cdot \mathrm{H}_{2} \mathrm{O}(\mathrm{m}=7.0053 \mathrm{mg})$, (e) $\mathrm{Sm}(\mathrm{L})_{3} \cdot \mathrm{H}_{2} \mathrm{O}(\mathrm{m}=7.2276 \mathrm{mg})$, (f) $\mathrm{Eu}(\mathrm{L}){ }_{3} \cdot \mathrm{H}_{2} \mathrm{O}(\mathrm{m}=7.3136 \mathrm{mg}),(\mathrm{g}) \mathrm{Gd}(\mathrm{L}){ }_{3} \cdot \mathrm{H}_{2} \mathrm{O}(\mathrm{m}=7.9607 \mathrm{mg})$. $\mathrm{L}=2$-methoxycinnamylidenepyruvate. 
Table 4. Temperature ranges $\theta$, mass losses $(\Delta \mathrm{m})$ and peak temperatures observed for each step of the TG-DTA curves of the compounds $\mathrm{Ln}(\mathrm{L}){ }_{3} \cdot \mathrm{H}_{2} \mathrm{O}$, where $\mathrm{Ln}=$ light lanthanides; $\mathrm{L}=2$-methoxycinnamylidenepyruvate

\begin{tabular}{|c|c|c|c|c|c|c|}
\hline \multirow{2}{*}{\multicolumn{2}{|c|}{ Compound }} & \multicolumn{5}{|c|}{ Steps } \\
\hline & & First & Second & Third & Fourth & Fifth \\
\hline & $\theta / \mathrm{K}$ & $333-393$ & $403-723$ & $723-813$ & $813-943$ & $943-993$ \\
\hline \multirow[t]{3}{*}{$\mathrm{La}(\mathrm{L})_{3} \cdot \mathrm{H}_{2} \mathrm{O}$} & $\Delta \mathrm{m} / \%$ & 2.18 & 42.02 & 32.47 & 1.93 & 2.5 \\
\hline & Peak / K & 371 (endo) & 641 (exo) & 790 (exo) & 923 (exo) & 985 (endo) \\
\hline & $\theta / \mathrm{K}$ & $333-393$ & $403-593$ & $593-723$ & - & - \\
\hline \multirow[t]{3}{*}{$\mathrm{Ce}(\mathrm{L})_{3} \mathrm{H}_{2} \mathrm{O}$} & $\Delta \mathrm{m} / \%$ & 2.14 & 26.73 & 50.90 & - & - \\
\hline & Peak / K & 368 (endo) & 543 (exo) & 645 (exo) & - & - \\
\hline & $\theta / \mathrm{K}$ & $333-393$ & $403-608$ & $608-643$ & $643-783$ & $803-843$ \\
\hline \multirow[t]{3}{*}{$\operatorname{Pr}(\mathrm{L})_{3} \cdot \mathrm{H}_{2} \mathrm{O}$} & $\Delta \mathrm{m} / \%$ & 2.01 & 30.88 & 16.18 & 29.78 & 1.1 \\
\hline & Peak / K & 368 (endo) & - & 629 (exo) & 489 (exo) & - \\
\hline & $\theta / \mathrm{K}$ & $333-393$ & $403-598$ & $598-643$ & $643-853$ & $853-923$ \\
\hline \multirow[t]{3}{*}{$\mathrm{Nd}(\mathrm{L})_{3} \cdot \mathrm{H}_{2} \mathrm{O}$} & $\Delta \mathrm{m} / \%$ & 2.20 & 29.34 & 33.01 & 4.94 & 1.2 \\
\hline & Peak / K & 368 (endo) & - & $636(\mathrm{exo})$ & 778 (exo) & - \\
\hline & $\theta / \mathrm{K}$ & $333-393$ & $403-613$ & $613-723$ & $723-823$ & $843-953$ \\
\hline \multirow[t]{3}{*}{$\mathrm{Sm}(\mathrm{L})_{3} \cdot \mathrm{H}_{2} \mathrm{O}$} & $\Delta \mathrm{m} / \%$ & 2.25 & 32.29 & 38.16 & 6.20 & 1.5 \\
\hline & Peak / K & 368 (endo) & - & 646 (exo) & 793 (ехо) & - \\
\hline & $\theta / \mathrm{K}$ & $333-393$ & $393-578$ & $578-658$ & $658-823$ & $823-973$ \\
\hline \multirow[t]{3}{*}{$\mathrm{Eu}(\mathrm{L})_{3} \cdot \mathrm{H}_{2} \mathrm{O}$} & $\Delta \mathrm{m} / \%$ & 2.06 & 47.93 & 21.69 & 6.36 & 1.68 \\
\hline & Peak / K & 373(endo) & $558(\mathrm{exo})$ & $638,648(\mathrm{exo})$ & 733(exo) & - \\
\hline & $\theta / \mathrm{K}$ & $333-393$ & $393-583$ & $583-663$ & $663-903$ & $903-973$ \\
\hline \multirow[t]{2}{*}{$\mathrm{Gd}(\mathrm{L})_{3} \cdot \mathrm{H}_{2} \mathrm{O}$} & $\Delta \mathrm{m} / \%$ & 1.93 & 25.64 & 41.83 & 8.48 & 1.24 \\
\hline & Peak / K & 373(endo) & $523(\mathrm{exo})$ & 643(exo) & 888(ехо) & - \\
\hline
\end{tabular}

by the corresponding TG curves, confirmed the evolution of $\mathrm{CO}_{2}$ in all cases. The formation of dioxycarbonate as intermediate had already been observed during the thermal decomposition of other lanthanide compounds. ${ }^{6}$

The last mass loss is ascribed to the thermal decomposition of the mixture of dioxycarbonate/oxide (calculated $=2.57 \%$ for $\mathrm{Pr} ; 2.56 \%$ for $\mathrm{Nd} ; 2.54 \%$ for $\mathrm{Sm}$; $1.68 \%$ for $\mathrm{Eu}$ and $1.24 \%$ for $\mathrm{Gd}$ ), to the respective oxides: $\mathrm{Pr}_{6} \mathrm{O}_{11}$ and $\mathrm{Ln}_{2} \mathrm{O}_{3}(\mathrm{Ln}=\mathrm{Nd}$ to $\mathrm{Gd})$, as final residues. No endothermic peak is observed in the DTA curve due to the thermal decomposition of the intermediate derivative of the carbonate, probably because the heat absorbed in this step is not sufficient to produce a thermal event. The mass losses, temperature ranges and the peak temperatures observed in each step of the TG-DTA curves are shown in Table 4.

The DSC curves of the compounds are shown in Figure 4. A heating rate of 40 degree $\mathrm{min}^{-1}$ was adopted because the curves obtained at 20 degree $\min ^{-1}$ exhibited very low resolution. These curves show endothermic and exothermic events that all agree with the mass losses observed in the TG curves. The endothermic peaks at $397 \mathrm{~K}$ (La), 396 K (Ce), 393 K (Pr), 396 K (Nd), 394 K (Sm),

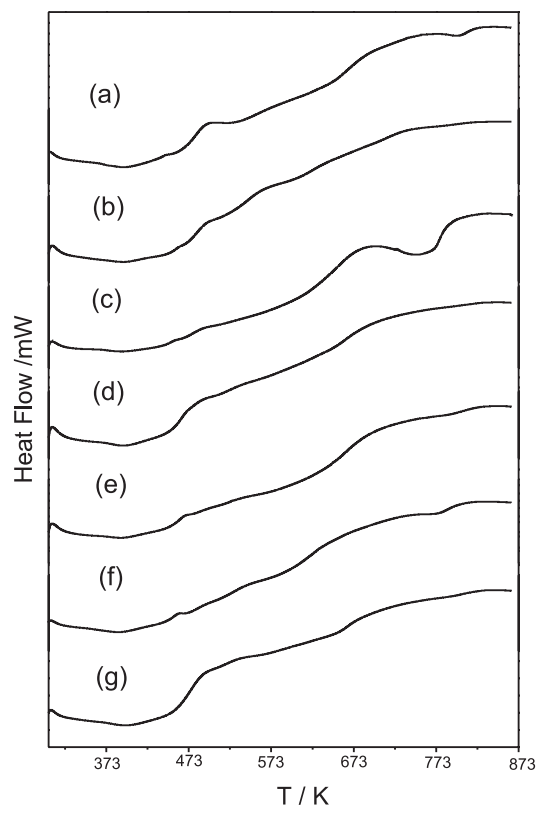

Figure 4. DSC curves of the compounds: (a) $\mathrm{La}(\mathrm{L})_{3} \mathrm{H}_{2} \mathrm{O}(\mathrm{m}=5.400 \mathrm{mg})$, (b) $\mathrm{Ce}(\mathrm{L})_{3} \cdot \mathrm{H}_{2} \mathrm{O}(\mathrm{m}=4.826 \mathrm{mg})$, (c) $\mathrm{Pr}(\mathrm{L})_{3} \cdot \mathrm{H}_{2} \mathrm{O}(\mathrm{m}=5.382 \mathrm{mg})$, (d) $\mathrm{Nd}(\mathrm{L})_{3} \cdot \mathrm{H}_{2} \mathrm{O}(\mathrm{m}=5.188 \mathrm{mg}),(\mathrm{e}) \mathrm{Sm}(\mathrm{L})_{3} \cdot \mathrm{H}_{2} \mathrm{O}(\mathrm{m}=4.725 \mathrm{mg})$, (f) Eu(L) $\mathrm{H}_{2} \mathrm{O}(\mathrm{m}=4.956 \mathrm{mg})$ and $(\mathrm{g}) \mathrm{Gd}(\mathrm{L})_{3} \cdot \mathrm{H}_{2} \mathrm{O}(\mathrm{m}=5.590 \mathrm{mg})$. $\mathrm{L}=2$-methoxycinnamylidenepyruvate. 
$389 \mathrm{~K}(\mathrm{Eu})$ and $400 \mathrm{~K}(\mathrm{Gd})$ are attributed to dehydration. The broad exotherms observed for all compounds between 443 and $873 \mathrm{~K}$ are attributed to the thermal decomposition of the anhydrous compounds, where the oxidation of the organic matter takes place in consecutive and/or overlapping steps.

The dehydration enthalpies found for these compounds (La to Gd) were: 29.6, 24.4, 25.3, 28.7, 27.6, 30.5 and $28.0 \mathrm{~kJ} \mathrm{~mol}^{-1}$, respectively.

\section{Conclusions}

All compounds synthesized in this work were obtained as monohydrates and were stable at room temperature. The first stage of complex decomposition corresponds to an endothermic process related to the release of water molecules.

The thermal decomposition of the anhydrous compounds occurs in four steps, except for the cerium (two steps), and the mass lost in each step is characteristic of each compound.

From the TG curves and the complexometry results, a general formula could be established for these compounds in the solid state.

The X-ray powder patterns verified that the synthesized compounds were obtained in the amorphous state.

The theoretical and experimental infrared spectroscopic data suggest that $2-\mathrm{MeO}-\mathrm{CP}$ acts as a bidentate ligand towards the metal ions considered in this work.

\section{Acknowledgments}

The authors wish to thank FAPESP, CAPES and CNPq (Brazil) for financial support, and the IQ-UNESP and Dr. Éder Tadeu Gomes Cavalheiro, from IQ-USP, São CarlosSP, for computational facilities.

\section{References}

1. Lubrzynska, E.; Smedley, I.; Biochem. J. 1913, 7, 375.

2. Dujardin, G.; Maudet, M.; Brown, E.; Tetrahedron Lett. 1997, 38, 1555 .

3. Siqueira, O. S.; Melios, C. B.; Ionashiro, M.; Moraes, M. de.; Molina, M.; J. Alloys Compd. 1995, 225, 267.

4. Pereira, N. C. S.; Melios, C. B.; Marques, R. N.; Siqueira, O. S.; Moraes, M. de; Molina, M.; Ionashiro, M.; J. Alloys Compd. 1997, 249, 94.

5. De Oliveira, J. D. S.; Leles, M. I. G.; D’ Assunção, L. M.; Melios, C. B.; Ionashiro, M.; J. Braz. Chem. Soc. 1999, 10, 209.

6. Leles, M. I. G.; Melios, C. B.; D’ Assunção, L. M.; Ionashiro, M.; Ecl. Quim. 1999, 24, 29.
7. Schnitzler, E.; Melios, C. B.; Ionashiro, M.; J. Therm. Anal. Calorim. 2002, 70, 581.

8. Oliveira, J. D. S. de; Fertonani, F. L.; Melios, C. B.; Ionashiro, M.; Ecl. Quim. 2002, 27, 11.

9. Carvalho, C. T. de; Siqueira, A. B.; Ionashiro, E. Y.; Pivatto, M.; Ionashiro, M.; Ecl. Quim. 2008, 33, 61.

10. Flaschka, H. A.; EDTA Titrations, Pergamon Press: Oxford, 1964.

11. Ionashiro, M.; Graner, C. A. F.; Zuanon Netto, J.; Ecl. Quim. 1983, 8, 29.

12. Becke, A. D.; J. Chem. Phys. 1993, 98, 5648.

13. Lee, C.; Yang, W.; Parr, R. G.; Phys. Rev. 1988, B37, 785.

14. Dunning Jr., T. H.; Hay, P. J. In Modern Theoretical Chemistry; Schaefer III, H. F., ed.; Plenum: New York, 1976, vol. 3, pp. 1-28.

15. Fuentealba, P.; Preuss, H.; Stoll, H.; Szntpaly, L. V.; Chem. Phys. Lett. 1989, 89, 418.

16. Frisch, M. J.; Trucks, G. W.; Schlegel, H. B.; Scuseria, G. E.; Robb, M. A.; Cheeseman, J. R.; Montgomery, Jr., J. A.; Vreven, T.; Kudin, K. N.; Burant, J. C.; Millam, J. M.; Iyengar, S. S.; Tomasi, J.; Barone, V.; Mennucci, B.; Cossi, M.; Scalmani, G.; Rega, N.; Petersson, G. A.; Nakatsuji, H.; Hada, M.; Ehara, M.; Toyota, K.; Fukuda, R.; Hasegawa, J.; Ishida, M.; Nakajima, T.; Honda, Y.; Kitao, O.; Nakai, H.; Klene, M.; Li, X.; Knox, J. E.; Hratchian, H. P.; Cross, J. B.; Adamo, C.; Jaramillo, J.; Gomperts, R.; Stratmann, R. E.; Yazyev, O.; Austin, A. J.; Cammi, R.; Pomelli, C.; Ochterski, J. W.; Ayala, P. Y.; Morokuma, K.; Voth, G. A.; Salvador, P.; Dannenberg, J. J.; Zakrzewski, V. G.; Dapprich, S.; Daniels, A. D.; Strain, M. C.; Farkas, O.; Malick, D. K.; Rabuck, A. D.; Raghavachari, K.; Foresman, J. B.; Ortiz, J. V.; Cui, Q.; Baboul, A. G.; Clifford, S.; Cioslowski, J.; Stefanov, B. B.; Liu, G.; Liashenko, A.; Piskorz, P.; Komaromi, I.; Martin, R. L.; Fox, D. J.; Keith, T.; Al-Laham, M. A.; Peng, C. Y.; Nanayakkara, A.; Challacombe, M.; Gill, P. M. W.; Johnson, B.; Chen, W.; Wong, M. W.; Gonzalez, C.; Pople, J. A.; Gaussian 03, Revision B.04, Gaussian, Inc., Pittsburgh PA, 2003.

17. Schlegel, H. B. In New Theoretical Concepts for Understanding Organic Reactions; Bertrán, J.; Csizmadia, I. G., eds.; Kluwer: Dordrecht, 1989, pp. 33-53.

18. Goodson, D. Z.; J. Phys. Chem. 1988, 86, 659.

19. Dennington II, R.; Keith, T.; Millam, J.; Eppinnett, K.; Hovell, W. L.; Gilliland, R.; Semichem, Inc.: Shawnee Mission, KS, 2003.

20. Tavale, S. S.; Pant, L. M.; Biswas, A. B.; Acta Crystallogr. 1961, $14,1281$.

Received: September 9, 2008 Web Release Date: June 18, 2009

FAPESP helped in meeting the publication costs of this article. 